\title{
Effect of Holistic Module of Yoga and Ayurvedic Panchakarma in Type 2 Diabetes Mellitus-A Pilot Study
}

\author{
Barve Vaibhavi, Tripathi Satyam, Patra Sanjibkumar, Nagarathna Raghuram, Nagendra H. Ramarao \\ Division of Life Sciences, SVYASA, Swami Vivekananda Yoga Anusandhana Samsthana, Bangalore, India \\ Email: barvevaibhavi@rediffmail.com
}

Received November 24, 2012; revised December 26, 2012; accepted January 28, 2013

\begin{abstract}
Objective: Ayurveda and Yoga have emerged as beneficial adjuvant in management of diabetes. This pilot study was planned to understand the concepts and assess the effect of a combination of Ayurvedic panchakarma and Yoga. Design: Experimental pilot study with pre post design. Subjects: Twelve patients with type 2 diabetes in age between $40-70$ years (mean $56 \pm 9.08$ ) with no cardiac, renal or retinal complications. Settings: Residential Holistic Health Centre of S-VYASA. Intervention: A validated Ayurveda protocol comprising of panchakarma followed by maintenance therapy with a specific module of Integrated Approach of Yoga Therapy for Diabetes that included selected physical postures (asanas), pranayama, meditation, lifestyle change and yogic counseling for stress management. All subjects underwent a residential program for six weeks followed by therapy at home for 12 weeks. Results were analyzed using paired "t" test. Results: After 6 weeks, Fasting Blood Glucose reduced ( $<$ 0.05) from $129.31 \pm 58.11$ to $103.54 \pm$ 40.74 (19.93\%), Post Prandial Blood Glucose from $191.69 \pm 76.77$ to $152.92 \pm 62.06$ (20.23\%, p < 0.05), Total cholesterol from $209 \pm 33.7$ to $186.92 \pm 23.36(10.56 \%$, p < 0.05), Triglycerides from $198.25 \pm 94.78$ to $151.25 \pm 43.65$ $(23.71 \%, \mathrm{p}<0.05)$, HbA1c reduced $(\mathrm{p}=0.014)$ from $8.79 \pm 2.12$ to $8.07 \pm 1.77(8.19 \%)$ in $6^{\text {th }}$ week and further to 7.63 $\pm 2.12(13.19 \%, p=0.001)$ after $12^{\text {th }}$ week. Oral Hypoglycemic Agent (OHA) drug score reduced from $2.83 \pm 0.93$ to 1 \pm 1.27 (64.66\%, p < 0.001). Symptom score reduced from $2.83 \pm 1.02$ to $1.66 \pm 0.65(\mathrm{p}<0.001)$. At baseline guna questionnaire showed six subjects each with rajas and tamas dominance. On post assessments, two subjects shifted from tamas to rajas dominance. Conclusion: This first pilot study has indication of a potentially beneficial effect of combining traditionally recommended Ayurveda panchakarma with maintenance herbs and Yoga, in reducing blood glucose and lipids. Long term RCT is recommended.
\end{abstract}

Keywords: Ayurveda; Yoga; Diabetes

\section{Introduction}

Diabetes mellitus imposes a sizeable burden globally in terms of early mortality, morbidity, and health care costs. The incidence of diabetes worldwide was likely to be $2.8 \%$ in 2000 and expected to rise to $4.4 \%$ by 2030 , and above three-quarters of people with diabetes would be living in developing countries [1]. Diabetes mellitus (madhumeha) was known to ancient Indian physicians with detailed description of its clinical features and management protocols [2]. Ayurveda is a comprehensive system of traditional health care, which originated in India approximately three thousand years ago. Its unique holistic approach appears to have become relevant today due to the increasing prevalence of non communicable diseases. This science of life deals with body, mind, and spirit as a single entity with clear understanding of the techniques of managing them. Ancient Ayurveda classics by Charaka, Sushruta, and Vagbhata contain ample literature about Prameha and its treatment. Prameha is a metabolic disorder and is diagnosed mainly with the help of signs and symptoms related to "Mutra" (Urine). Genetic predisposition with sedentary life style, injudicious intake of food, and stress are recognized as some of the important etiological factors of Prameha, [3]. The diagnosis and management of diabetes (madhumeha) is based on tridosa (bodily humor) theory which says that kapha (phlegm), pitta (bile) and vata (wind) are the basic pillars of life [4]; balanced functioning of these tridosas is health and imbalance is disease [5]. A disturbance in the doshas precedes the genesis of various pathological states which results to 20 types of Prameha where finally diabetes (madhumeha) is one of the chronic type of Prameha. Thus, the primary aim in prevention, diagnosis and treatment of a disease is to detect the degree of vitiation in these doshas.

Several studies have shown the beneficial effects of Ayurveda in T2DM with significant reduction in Glycosylated Haemoglobin (HbA1c), Fasting and Post Prandial 
Blood Glucose (FBG, PPBG) levels and lipids [6-8]. A study by Ahmed et al. that treated diabetic rats with the fruit juice of Momordia charantia has reported regeneration or increase in the number of beta cells [9], which appears to offer some evidence to the additional benefits of Ayurveda because none of the conventional Oral Hypoglycemic Agents (OHA) exhibit this property. Momordia charantia also has exhibited extra-pancreatic effects with improved peripheral glucose utilization [10]. Recent studies [11,12] have described the role of a few herbs like Trigonella foenum graecum and Tinospora cordifolia on activities of enzymes involved in carbohydrate and lipid metabolism. In animal based studies, herbs like Curcuma longa have shown reduction in dyslipidemia in diabetics [13] through its effect on lipid peroxidation [14].

Ayurveda being a holistic science, it has to be practiced as a whole science including several steps of management and cannot be given only as one capsule of a proven herbal preparation. Hence it was necessary to review the classical texts and compile them to present a holistic management protocol in the form of flow chart with different steps, which was finally done and sent for validation from various Ayurveda experts [15].

Yoga is also one of the modalities in Complimentary and Alternative Medicine (CAM) which is an integral part of Ayurveda (mentioned in classical texts) [16]. Yoga is found to be very effective as a complimentary treatment for type 2 diabetes in several studies [17-19]. Studies have demonstrated significant reduction in FBG, PPBG [20-22] Glycosylated Haemoglobin (HbA1c) [22], improvement in nerve functions [22], reduction in oral glycemic agents [23] and Body Mass Index (BMI) [24] after the practice of Yoga.

Multiple factors involved in the pathogenesis of diabetes demands a multi-modal remedial approach [25]. Although there are many studies that reveal the efficacy of CAM modalities, there are very few studies which report the efficacy of these modalities when used together. Since there are ample evidences that Ayurveda can be a potential complimentary therapy for diabetes [6-8], it would be worthwhile to test its efficacy when combined with Yoga, which is also one of the CAM modalities having large number evidence based studies supporting its effect in type 2 diabetes.

Hence this pilot study was planned with an intention of assessing the feasibility and safety of this residential Ayurveda and Yoga therapy before launching a controlled study on a larger population.

\section{Materials and Methods}

\subsection{Subjects}

Twelve ( $\mathrm{n}=12)$ subjects ( 7 female, 5 male) in age range of 40 - 70 years (mean $56 \pm 9.08$ ) with Type 2 Diabetes Mellitus (T2DM) were recruited for the study. The sample size was calculated based on an effect size (Cohen's effect size, $\varepsilon=2.45$ ) obtained from a previous study of changes following the practices of Yoga in DM patients [16]. It was calculated using G*Power software, Version 3.0.10, where the level was 0.05 and power $=$ 0.95 and the recommended sample size was twelve. Thus, a sample size of twelve was recruited for the present study. Subjects who satisfied the American Diabetes Association (ADA) criteria for T2DM [26], not practicing Yoga for at least previous three months and willing to participate in the trial were included. Those with cardiac complications and nephropathy were excluded after checking ECG, FBG, blood urea, and creatinin. Those with proliferative retinopathy (screened by an ophthalmologist) and had practiced Yoga in the recent past (three months) were also excluded. Ethical clearance was obtained from institutional ethical committee. Signed informed consent was obtained from all subjects.

\subsection{Design}

This was an experimental pilot study with a pre post design in a single group.

\subsection{Methods}

All subjects went through a daily routine (Table 1) that included Integrated Approach of Yoga Therapy for Diabetes (IAYTD) along with a progressive plan of panchakarma (purificatory therapy) and maintenance herbs.

The protocol had the flexibility for changes in medication or Yoga practices based on their daily response assessments. After admission, first week was planned for stabilization of the baseline parameters without any intervention. The fasting (12-hr) blood sample was obtained via a veni-puncture in the arm with the individual in an upright position and after at least $5 \mathrm{~min}$ in a resting state. Supervised intervention with strict adherence to the schedule was followed from the beginning of second to end of fifth week. The clinical progress was monitored daily by one Ayurveda and one allopathic physician; therapies were carried out by certified therapists and documentation was done by the research team. The subjects were monitored daily for symptoms scores, medication scores (number of OHA tablets per day), pulse rate, blood pressure, respiratory rate and blood glucose (glucometer). Diet was planned based on nutritional and dosha assessments. Post assessments were done in sixth week when the patients continued to remain in the campus attending the same daily routine on their own without instructions by the therapists. After discharge they were given the diet chart, personalized Yoga chart with instruction DVD, and maintenance medication. Home 
Table 1. Ayurveda protocol.

\begin{tabular}{|c|c|}
\hline \multicolumn{2}{|c|}{ Ayurveda protocol } \\
\hline Treatment plan & $\begin{array}{l}\text { Drugs used in treatment plan } \\
\text { with their dosage and time }\end{array}$ \\
\hline $\begin{array}{l}\text { Appetizer, digestive drugs } \\
\text { (Deepana/Paachan) for } 3 \text { - } 7 \\
\text { days }\end{array}$ & $\begin{array}{l}\text { Trikatu churna [27] } 2 \text { gms twice } \\
\text { daily before food }\end{array}$ \\
\hline $\begin{array}{l}\text { Internal oleation for } 3 \text { - } 7 \\
\text { days (Snehapaan) }\end{array}$ & $\begin{array}{l}\text { Sarshapa tail [28] } \\
\text { 30ml/60ml/90ml in increasing } \\
\text { dose }\end{array}$ \\
\hline $\begin{array}{l}\text { External oleation with } \\
\text { sudation (Abhyanga/Swedan) } \\
\text { for } 3 \text { days }\end{array}$ & $\begin{array}{l}\text { Brihat saindhavadi Taila [29] } \\
\text { (external application) }\end{array}$ \\
\hline Purgation (Virechan) 1 day & Trivrit lehyam [30] 30 - 60 gms \\
\hline $\begin{array}{l}\text { Post purgation diet } \\
\text { restrictions } \\
\text { (Samsarjana/Krama ) for } 3 \text { - } \\
5 \text { days }\end{array}$ & - \\
\hline $\begin{array}{l}\text { Palliative therapy (Shamana) } \\
\text { to be continued }\end{array}$ & $\begin{array}{l}\text { Kathakhadiradi kashaya [31] } 15 \\
\text { ml twice daily. Amritmehari } \\
\text { churna [32] } 2 \text { gms twice daily. } \\
\text { Shilajatwadi vati [33] } 2 \text { tabs } \\
\text { thrice daily }\end{array}$ \\
\hline
\end{tabular}

practice was monitored up to 12 weeks by regular motivating phone calls. HbA1c was assessed at the end of twelfth week.

\subsection{Intervention}

A validated Ayurveda protocol developed on the basis of classical scriptural references was used which included panchakarma followed by maintenance medication (Table 2). Along with Ayurveda protocol, the module of Integrated Approach of Yoga Therapy (IAYTD) for diabetes comprised of Yogasanas, Pranayama, meditation and lectures as used in our two earlier studies in India [23,34] and UK [17] (Table 3).

\subsection{Outcome Measures}

Ama, agni and kostha were assessed at baseline using a check list prepared for the purpose of this study based on guidelines in classical texts. Agni was scored on a three point scale 1 = mandagni (less digestive capacity), 2 = madhyagni (medium digestive capacity) and $3=$ pravaragni (more digestive capacity). The end point of the cleansing procedure was considered to be when ama score reached a balanced score of 1 . Koshta (colonic sensitivity) was assessed based on seven questions with three response choices. A total score of 1 to 7 indicates mrudu koshta (more colonic sensitivity), 8 to 18 madhyam koshta (medium colonic sensitivity) and 19 to 21 krura koshta (less colonic sensitivity). These assessments were done at baseline and daily for assessing the effect of panchakarma procedure.
Table 2. Daily schedule of subjects.

\begin{tabular}{|c|c|c|}
\hline \multicolumn{3}{|c|}{ Daily schedule of subjects } \\
\hline Time (hours) & $\begin{array}{l}\text { Duration } \\
\text { (minutes) }\end{array}$ & Yoga practice \\
\hline $5.00-5.30$ & 30 & Om meditation \\
\hline $5.30-6.30$ & 60 & $\begin{array}{l}\text { Yoga based special technique } 1 \\
\text { (physical practices)/kriyas }\end{array}$ \\
\hline $6.30-7.30$ & 60 & Bath and wash \\
\hline $7.30-8.15$ & 45 & Lecture on bhagvadgita/chanting \\
\hline $8.15-8.45$ & 30 & Breakfast \\
\hline $8.45-10.00$ & 75 & Rest \\
\hline $10.00-11.00$ & 60 & $\begin{array}{l}\text { Lecture (on ayurvedic and yogic } \\
\text { lifestyle) }\end{array}$ \\
\hline $11.00-12.00$ & 60 & Pranayama (breathing practices) \\
\hline $12.00-13.00$ & 60 & $\begin{array}{l}\text { Yoga based special technique } 2 \\
\text { (physical practices) }\end{array}$ \\
\hline $13.00-14.00$ & 60 & Lunch (vegetarian diabetic diet) \\
\hline $14.00-14.30$ & 30 & Deep Relaxation Technique (DRT) \\
\hline $14.30-16.00$ & 90 & $\begin{array}{l}\text { Assessments, psychological and } \\
\text { yogic counseling }\end{array}$ \\
\hline $16.00-17.00$ & 60 & Cyclic Meditation (CM) \\
\hline $17.00-18.00$ & 60 & Tuning to nature \\
\hline $18.00-19.00$ & 60 & Divine hymns session (Bhajan) \\
\hline $19.00-19.45$ & 45 & Mind sound resonance technique \\
\hline $19.45-20.30$ & 45 & Dinner ( vegetarian diabetic diet) \\
\hline $20.30-21.30$ & 60 & $\begin{array}{l}\text { Cleansing technique for eye } \\
\text { (Trataka) }\end{array}$ \\
\hline $21.30-22.00$ & 30 & Self study \\
\hline 22.00 & - & Lights off \\
\hline
\end{tabular}

\subsubsection{Symptom Score}

The average severity of all symptoms documented before and after the 6 weeks was recorded. Severity was scored on a 4-point scale of $0-3(0=$ nil, 1 -mild not disturbing the daily routine, 2 = moderate-disturbs routine requires symptomatic medication, $3=$ severe-require hospitalization or parenteral medication).

\subsubsection{Medication Score}

Number of tables of Oral Hypoglycemic Agent (OHA)/day; 1 tablet $=$ the standard strength each for adults quoted in pharmacopeia index e.g. one tablet of Metformin $=500 \mathrm{mg}$.

\subsubsection{Guna Assessment}

The G-Inventory [35] (GI) assessed the shift of guna dominance after the intervention. GI is a measure of the 
Table 3 Demographic details of the subject

\begin{tabular}{|c|c|c|c|c|c|c|c|c|c|c|}
\hline Sub no. & Name & $\begin{array}{c}\text { Age } \\
\text { (years) }\end{array}$ & $\begin{array}{c}\text { Sex } \\
(\mathrm{M} / \mathrm{F})\end{array}$ & $\begin{array}{l}\text { Duration of } \\
\text { DM in years }\end{array}$ & $\begin{array}{c}{ }^{* *} \text { Family } \mathrm{H} / \mathrm{O} \\
\text { DM }\end{array}$ & $\begin{array}{l}\text { Creatinine } \\
(\mathrm{mg} / \mathrm{dl})\end{array}$ & $\begin{array}{l}\text { Urea } \\
\text { (mg/dl) }\end{array}$ & Agni & Ama & Kostha \\
\hline 1 & SS & 69 & M & 03 & $\mathrm{~N}$ & 1.3 & 30.8 & 1 & 3 & 19 \\
\hline 2 & AS & 48 & $\mathrm{~F}$ & 5.5 & $\mathrm{~N}$ & 0.78 & 29.4 & 3 & 3 & 9 \\
\hline 3 & MG & 55 & M & 12 & $\mathrm{~N}$ & 0.90 & 30.3 & 1 & 3 & 9 \\
\hline 4 & $\mathrm{R}$ & 68 & $\mathrm{~F}$ & 08 & $\mathrm{~N}$ & 0.7 & 28 & 1 & 3 & 12 \\
\hline 5 & $\mathrm{H}$ & 56 & $\mathrm{~F}$ & 15 & F & 0.86 & 34.2 & 1 & 3 & 8 \\
\hline 6 & TC & 49 & $\mathrm{~F}$ & 14 & $\mathrm{M} / \mathrm{B}$ & 0.85 & 18.6 & 3 & 2 & 9 \\
\hline 7 & BS & 50 & $\mathrm{~F}$ & 16 & $\mathrm{~B} / \mathrm{S}$ & 0.86 & 21.7 & 1 & 3 & 7 \\
\hline 8 & AS & 40 & $\mathrm{M}$ & 04 & B & 0.72 & 22.8 & 1 & 3 & 18 \\
\hline 9 & $\mathrm{Hu}$ & 52 & M & 07 & $\mathrm{~N}$ & 0.8 & 39.5 & 2 & 3 & 19 \\
\hline 10 & A & 61 & $\mathrm{~F}$ & 11 & S & 1.0 & 20.0 & 1 & 3 & 11 \\
\hline 11 & S & 63 & $\mathrm{~F}$ & 25 & GF & 1.0 & 23.0 & 2 & 2 & 13 \\
\hline 12 & D & 66 & $\mathrm{M}$ & 9 & B & 1.2 & 19.0 & 1 & 3 & 7 \\
\hline
\end{tabular}

${ }^{* *}$ F — Father, M-Mother, B-Brother, S-Sister, GF-Grandfather, GM-Grandmother, N-Nil history.

three gunas (sattva, rajas and tamas) and contains ten questions with three response choices. A total score of above 28 indicates sattva, 24 to 28 rajas and $<24$ tamas. This test has a test retest reliability of 0.60 with a confidence level of $99 \%$ and has been validated. Biochemical parameters: these included Fasting (FBG) and Post Prandial Blood Glucose (PPBG), HbA1c and lipid profile determined at baseline and at the end of $6^{\text {th }}$ week. HbA1c was repeated at end of $12^{\text {th }}$ week. A semi-auto analyzer was used for the biochemical measurements. Blood Glucose was determined by enzymatic oxidation method using glucose peroxidase [36]. HbA1c was estimated by glucose oxidase method and cation-exchange resin method [37]. Cholesterol was determined after enzymatic hydrolysis and oxidation [38]. Triglycerides were determined after enzymatic splitting with lipoprotein lipase. Indicator for the same was generated from 4-aminoantipyrine and 4-chlorophenol by hydrogen peroxide under the catalytic action of peroxidase. LDL-VLDL Cholesterol was determined by using Friedewald's equation [39].

\section{Statistical Analysis}

Data were analyzed using SPSS version 16.0; checked for normal distribution by Shapiro Wilk's test. As the data were normally distributed for all variables student's paired samples " $\mathrm{t}$ " test was used with a significance value set at 0.05 for two-sided hypothesis testing.

\section{Results}

Table 3 gives the demographic characteristics of subjects.
The mean age was $56 \pm 9.08$ years. None had cardiac, renal or retinal complications. There were no drop outs in this study. At baseline, 2 subjects had madhyam ama and 10 had pravara ama, while 10 subjects had manda agni and 2 had madhyam agni and 3 subjects had mrudu kostha, 7 had madhyam kostha and 2 had krura kostha. Table 4 shows the results after the intervention.

After 6 weeks of intervention, the symptom score reduced from $2.83 \pm 1.02$ to $1.66 \pm 0.65(\mathrm{p}<0.001)$. OHA score reduced $(\mathrm{p}<0.001)$ from $2.83 \pm 0.93$ to $1 \pm 1.27$ (64.66\%). FBG reduced $(\mathrm{p}<0.05)$ from $129.31 \pm 58.11$ to $103.54 \pm 40.74$ (19.93\%). PPBG decreased from $191.69 \pm 76.77$ to $152.92 \pm 62.06(20.23 \%$, p < 0.05$)$. HbA1c reduced $(\mathrm{p}=0.014)$ from $8.79 \pm 2.12$ to $8.07 \pm$ $1.77(8.19 \%)$ in $6^{\text {th }}$ week. It reduced further to $7.63 \pm$ $2.12(13.19 \%, p=0.001)$ after $12^{\text {th }}$ week. At baseline guna questionnaire showed 6 subjects each with rajas and tamas dominance. On post assessments, two subjects shifted from tamas to rajas dominance. All of them had balanced functioning of agni, ama and kostha at the end of 6 weeks.

Lipid profile: Total Cholesterol decreased significantly $(\mathrm{p}<0.05)$ from $209 \pm 33.7$ to $186.92 \pm 23.36$ (10.56\%). Triglycerides reduced $(\mathrm{p}<0.05)$ from $198.25 \pm 94.78$ to $151.25 \pm 43.65$ (23.71\%). There was non-significant reduction in the levels of LDL, VLDL and HDL.

\section{Discussion}

This pilot study on twelve subjects with T2DM has shown significant reduction in FBG, PPBG, HbA1c, TC and TG along with reduction in oral hypoglycemic 
Table 4. Results after the intervention.

\begin{tabular}{|c|c|c|c|c|}
\hline \multicolumn{5}{|c|}{ Post intervention changes ${ }^{\#}$} \\
\hline Variables & $\begin{array}{l}\text { Pre }\left(1^{\text {st }} \text { week }\right) \\
\text { Mean } \pm \text { SD }\end{array}$ & $\begin{array}{l}\left.\text { Post (6 } 6^{\text {th }} \text { week }\right) \\
\text { Mean } \pm \text { SD }\end{array}$ & $\begin{array}{l}\text { Post2 }\left(12^{\text {th }} \text { week }\right) \\
\text { Mean } \pm \text { SD }\end{array}$ & p-value \\
\hline Medication scores & $2.83 \pm 0.93$ & $1 \pm 1.27^{* * *}$ & - & 0.001 \\
\hline Symptom score & $2.83 \pm 1.02$ & $1.66 \pm 0.65^{* * *}$ & - & 0.001 \\
\hline FBG & $129.31 \pm 58.11$ & $103.54 \pm 40.74^{*}$ & - & 0.017 \\
\hline PPBG & $191.69 \pm 76.77$ & $152.92 \pm 62.06^{*}$ & - & 0.013 \\
\hline HbA1c & $8.79 \pm 2.12$ & - & $7.63 \pm 2.12^{* * *}$ & 0.001 \\
\hline Total Cholesterol & $209 \pm 33.7$ & $186.92 \pm 23.36^{*}$ & - & 0.024 \\
\hline Total Triglycerides & $198.25 \pm 94.78$ & $151.25 \pm 43.65^{*}$ & - & 0.020 \\
\hline LDL & $129.42 \pm 29.63$ & $115.25 \pm 15.63$ & - & 0.121 \\
\hline VLDL & $39.65 \pm 18.96$ & $38.5 \pm 33.5$ & - & 0.907 \\
\hline
\end{tabular}

${ }^{*} \mathrm{p}<0.05,{ }^{* *} \mathrm{p}<0.01,{ }^{* * *} \mathrm{p}<0.001$, baseline data compared with the post data using a paired “t” test. Fasting Blood Glucose (FBG), Post Prandial Blood Glucose (PPBG), Glycosylated Hemoglobin (HbA1c), Total Cholesterol (TC), Total Triglycerides (TG), Low Density Lipoprotein (LDL), Very Low Density Lipoprotein (VLDL). "Note: These significant values stated are based on single group pre comparison to post. There is no control group which is an imitation of this study and that can also effect p-values when compared with control groups in main efficacy study.

medication and balanced functioning of agni, ama and kostha after six weeks of residential intervention using Yoga and Ayurveda.

\subsection{Comparisons}

To the best of our knowledge, there are no studies which report the effect of a combination of Yoga and Ayurveda (panchakarma and maintenance therapy) although there are studies on these two therapeutic modalities used independently in comparison to conventional medicine. Kumari et al. [8]. Assessed the effect of panchakarma followed by maintenance ayurvedic herbal therapy in forty two subjects with T2DM, which showed significant reduction in FBG and PPBG by $10.2 \%$ and $6.4 \%$ respectively after one month of intervention. In one of our earlier Yoga studies we had observed a decrease in FBG and HbA1c by $6.9 \%$ and $15.5 \%$ after an integrated Yoga protocol in a control study on diabetics in London [17]. Sahay et al. showed that Yoga was effective in reducing TC (by $0.47 \%$ ) and TG (by 18.03\%) [25]. In comparison, the present study has shown reduction in mean values of FBG (19.9\%), PPBG (20.2\%), HbA1c (13.2\%), TC (10.6\%), and TG (23.7\%). These values (except HbA1c) showed higher magnitude of change than the independent Yoga or Ayurveda studies. There are other studies on Ayurveda in T2DM that have shown encouraging results. Elder et al. randomized 60 adults with newly diagnosed T2DM (baseline HbA1c of 6.0 to 8.0) into experimental and control groups. The Ayurveda protocol included Ayurvedic diet, meditation and Ayurvedic herbal supplement (MA 471). The results showed significant difference between groups (ANCOVA) in HbA1c, FBG, TC, LDL and body weight in those who had higher baseline HbA1c [6]. Saxena and Vikram reviewed the accumulated literature on ten herbs with antidiabetic activity and reported that momordica charantia, pterocarpus marsupium and trigonella foenum greacum have beneficial effects in treating T2DM [40]. The results of many other studies on Yoga are also consistent with the outcomes of present study [17]. Yoga nidra (a form of guided relaxation) resulted in decreased FBG, PPBG, in patients with T2DM [41]. Looking at cardiac functions Singh et al. showed that training in Yoga asanas for forty days in 24 T2DM decreased their pulse rate, blood pressure, and Corrected QT interval in addition to decrease in FBG (25.5\%), PPBG (27.03\%) and HbA1c (13.3\%) [42]. A randomized control study that used Nadishodhana Pranayama and Sun Salutation for 5 weeks in twenty T2DM has shown significant decrease in plasma glucose, serum cortisol and serum Malone-Di-Aldehyde (MDA) levels and a significant increase in serum Super Oxide Dismutase (SOD) activity, more prominently in those who has poor glycemic control [43].

\subsection{Mechanism}

According to the present day molecular biological understanding of T2DM, the etiology is traceable to erratic life style that promotes expression of the diabetes related genes [44]; this results in a series of imbalances [calorie intake-out put = obesity, adipoleptin-nectin = IR; [45] proinflammatory-anti-inflammatory cytokines $=$ tissue 
inflammation [46] resulting in insulin resistance which in turn is responsible for the biochemical changes and the clinical manifestations. Thus, the benefits may be traced to reduction in oxidative stress mediators, modified HPA axis [47], reduction in adipoleptin [48], and pro-inflammatory cytokines [49] that are known to induce IR. The mechanism described by Yoga and Ayurveda offers a different model of understanding T2DM. Accordingly, diabetes is the effect of erratic life style that has resulted from lack of mastery over the mind and wrong notion about the meaning and purpose of life (prajnaparadha). The flow chart in Table 5 shows the pathogenesis of T2DM. Yoga masters proposed that the human system is made of five levels of subtle bodies [annamaya (physical), pranamaya (vital energy), manomaya (mental), vijnanamaya (intellectual) and anandamaya (bliss) kosas] [50]. Three gunas (satva, rajas and tamas) that grossify into three doshas (vata, pitta and kapha) constitute the physical body (annamaya kosha). Man is in best of health when there is a balanced functioning of the tridosas which is possible when the mind is in a state of satva (freedom from stress) and established in anandamaya kosha. T2DM, madhumeha [8] is a tridoshaja vyadhi, i.e. there is vitiation of all three dosas which is preceded by imbalance of the three gunas [dominance of tamas and/or rajas]. T2DM, a life style disease (samanya adhija vyadhi), begins in manomaya kosha. This is due to lack of right knowledge (a function of vijnanamaya kosha) that "I am made of happiness and freedom from all thoughts". This leads to craving for happiness from outside objects (wealth and fame). Long standing stresses (due to unsatisfied desires) leads to sleeplessness, irritability, indecisiveness, depression, and/or frustration (violent negative emotions). The long standing suppressed emotions are characterized by uncontrolled rewinding of thoughts in the mind (yogic definition of stress).This habituated uncontrolled speed percolates in to the pranamaya kosha and drains large quantities of prana leading to early aging (DM is an aging disease). This uncontrolled habituated speed results in an imbalance that further settles down in the physical body as structural damage (inflammation = speed at annamaya kosha). This descent (prasava) from a balanced state of functioning of the mind-body complex results in an imbalance of the three doshas. Caraka, the father of Ayurveda, describes T2DM as a disease characterized by covering (avarana) of excess kapha over vata that leads to obstruction in the harmonious movement of vata, and this obstructed/restricted movement in turn leads to stagnation and unavailability of pitta that is responsible for healthy metabolic processes in tissues. In addition, the obstructed vata gets aggravated and gets vitiated further [51]. Thus, T2DM begins with wrong life style due to adnyana (pragnaparadha) that leads to kapha dosha or tamo guna pradhanaka vihara and ahara (sedentary life- style, day time sleeping, excessive intake of fermented foods, oily foods, excess sweets and meat). This domi- nance of kapha results in agnimandya (improper func- tioning of digestive fire). This goes on to produce excess ama (endotoxins) which blocks the channels (srotas) thus preventing the balanced flow of vata. The vitiated kapha circulates throughout the body resulting in dhatwagni mandya (poor functioning of digestive fire at tissue level). It affects the dushya structures, the dhatus (tissues). Adipose tissue (medas) is the first dushya to be affected. Then it goes on to affect all other structures of the body including muscular tissue (mansa), intracellular and extra cellular fluids (kleda), vasa (muscle fat), shukra (semen), rakta (blood), majja (marrow tissue), rasa (blood plasma), lasika (fluids \& plasma) and ojas (vital substance that maintains immunity). Mutravaha srotas is the main channel to be affected that leads to madhumeha [52].

The holistic module of management of T2DM is based on measurement of the status of guna, the genetic personality type (prakrti), the present state of imbalance of the doshas (vikrti), the status of dushya, srotas, agni and ama at all stages of therapy.

It includes manifold techniques that possess the ability to reinstate homeostasis (pratiprasava) through increasing the satva guna and balancing the vitiated doshas. The integrated approach to yoga therapy (IAYT) prescribes practices at all the five koshas to arrive at complete mastery over the modifications of mind and remain in a state of inner contentment and joyful existence under all circumstances of life. The physical practices begin with cleansing the system of all endotoxins. This is achieved through satkriyas (Yoga) or panchakarma (Ayurveda). The stepwise progression of panchakarma starts with stimulating the excretion of the endotoxins (ama) through Snehana-Abhyangam (external and internal oleation through medicated massage) and swedana (induced sweating) followed by Virechana that helps in dislodging the vitiated doshas (excess kapha and pitta) [8] through purgation. This is followed by sanshamana (soothing relaxation) through herbal therapies for maintenance of balance. Thus, panchakarma removes ama, reduces kapha, clears the avarana (covering), cleanses the srotas, improves agni, promotes normal flow of vata, normalizes pitta and restores dhatwagni that promotes normal functioning of dhatus. IAYT, a mind body intervention adds on the component of self corrective processes to restore balance at all levels through deep rest. In summary, avoiding the etiological factors (nidan parivarjana) through lifestyle change [by mind mastery through jnana Yoga (right knowledge), raja Yoga, karma Yoga and bhakti Yoga] [55], detoxification through panchakarma, 
Table 5. Pathophysiology and management of Type 2 Diabetes Mellitus according to Ayurveda, Yoga and biomedicine.

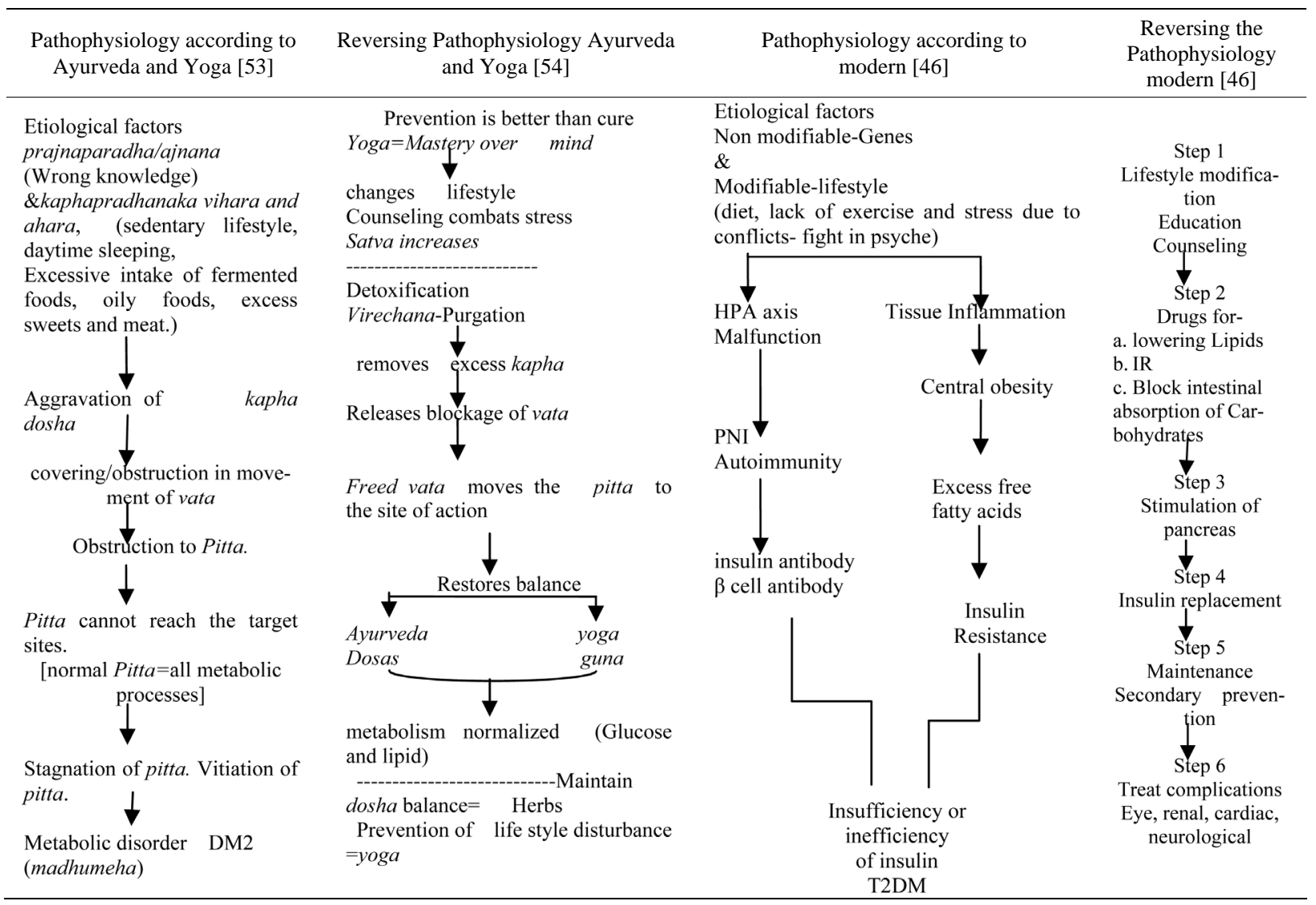

correct the dosha imbalance and clear the subtle channels through medication, asanas and pranayama forms the basis of this integrated Yoga and Ayurveda model used in this program. Long term regular monitoring is necessary to prevent return of the imbalance that is genetically determined in T2DM. This is ensured by lifelong regular IAYT and medication.

\section{Strength of the Study}

This is the first attempt to test the efficacy of multi modalities of CAM in a residential setting using standard tools of assessment. The development of an integrated module by an exhaustive search of all available texts of Ayurveda and Yoga (16 texts) with a sound conceptual basis for the holistic approach is the major contribution of this study. Rendering the traditional knowledge in an acceptable capsule for the present day elite community of diabetics has been achieved by this pilot study.

\section{Limitations of the Study}

Sample size was small and no control group was planned. There is lack of a control group using either of Yoga and Ayurveda, the comparison with other single method study is not very valid. As this was a pilot study and not an efficacy trial the conclusions from the study are only pointers to a larger study and not a proof of concept.

\section{Implications and Suggestions for Future Work}

The Yoga and Ayurveda model of etio-pathogenesis of T2DM based on the concepts of imbalance of gunas and doshas offers an opening to subtler dimensions Holistic way of understanding of this disease and may bring about a paradigm shift in diabetes research. This pilot study has prepared the ground for a four armed control study that has been funded by dept. of AYUSH, ministry of health and family welfare, Govt. of Karnataka, India. Statistically acceptable sample sizes, with a battery of assessment of the cognitive functions (subjective and objective), autonomic functions along with biochemical, molecular, genetic, immunological variables has been included in the proposed project.

\section{Conclusion}

This pilot study has shown the safety, feasibility and indication of a potentially beneficial effect of an integrated Yoga and Ayurveda module in achieving good glycemic control and lipid profile with reduced requirement of 
Oral Hypoglycemic Agents in patients with T2DM. This has prepared the ground for an efficacy trial.

\section{Acknowledgements}

We thank the faculty of Susruta Ayurveda College, Bangalore for their help in preparing the module of Ayurveda protocol. We thank the therapists of S-VYASA for their support in carrying out the study. We thank Dr. Pradhan B. for his support with statistics and Dr. Haldavnekar R. for her continuous support during the study.

\section{REFERENCES}

[1] S. Wild, G. Roglic, A. Green, R. Sicree and H. King, "Global Prevalence of Diabetes: Estimates for the Year 2000 and Projections for 2030," Diabetes Care, Vol. 27, No. 5, 2004, pp. 1047-1053. doi:10.2337/diacare.27.5.1047

[2] V. P. Upadhyay and P. Kamla, "Ayurvedic Approach to Diabetes Mellitus and Its Management by Indiginous Resources,” In: J. S. Bajaj, Eds., Diabetes Mellitus in Developing Countries, Interprint, New Delhi, 1984, pp. 375-377.

[3] B. Tripathi, "Sarangadhara Samhita of Sharangadharacharya," In: Chaukhamba Surbharati Prakashana, Varanasi, 2010, p. 101.

[4] G. K. Garde, "Sartha Vaghbhata,” In: Sutrasthana 6th Verse, Raghuvamshi Publishers, Pune, 1996, p. 2.

[5] G. K. Garde, “Sartha Vaghbhata,” In: Sutrasthana 7th Verse, Raghuvamshi Publishers, Pune, 1996, p. 2.

[6] C. Elder, M. Aickin, V. Bauer, J. Cairns and N. Vuckovic, "Randomized Trial of a Whole-System Ayurvedic Protocol for Type 2 Diabetes," Alternative Therapies in Health and Medicine, Vol. 12, No. 5, 2006, pp. 24-30.

[7] T. Ila, H. M. Chandola and J. R. Joshi, "Clinical Efficacy of Mehamudgara Vati in Type 2 Diabetes Mellitus,” Ayu, Vol. 32, No. 1, 2011, pp. 30-39. doi:10.4103/0974-8520.85722

[8] J. Kumari, C. S. Mehta, V. D. Shukla, A. R. Dave and T. M. Shingala, "A Comparative Clinical Study of Nyagrodhadi Ghanavati and Virechana Karma in the Management of Madhumeha," Ayu, Vol. 31, 2010, pp. 300-304. doi:10.4103/0974-8520.77152

[9] I. Ahmed, I. Chandranath, A. K. Sharma, E. Adeghate, D. J. Pallot and J. Singh, "Mechanism of Hypoglycemic Action of Momordica Charantia Fruit Juice in Normal and Diabetic Rats,” The Journal of Physiology, Vol. 520, 1999.

[10] I. Ahmed, E. Adeghate, A. K. Sharma, D. J. Pallot and J. Singh, "Effects of Momordica Charantia Fruit Juice on Islet Morphology in the Pancreas of the StreptozotocinDiabetic rats,” Diabetes Research and Clinical Practice, Vol. 40, No. 3, 1998, pp. 145-151. doi:10.1016/S0168-8227(98)00022-9

[11] J. Raju, D. Gupta, A. R. Rao, P. K. Yadava and N. Z. Baquer, "Trigonella Foenum Graecum (Fenugreek) Seed Powder Improves Glucose Homeostasis in Alloxan Diabetic Rat Tissues by Reversing the Altered Glycolytic, Gluconeogenic and Lipogenic Enzymes," Molecular and
Cellular Biochemistry, Vol. 224, No. 1-2, 2001, pp. 45-51. doi:10.1023/A:1011974630828

[12] P. Stanely, M. Prince and V. P. Menon, "Hypoglycemic and Other Related Actions of Tinospora Cordifolia Roots in Alloxan-Induced Diabetic Rats," Journal of Ethnopharmacology, Vol. 70, No. 1, 2000, pp. 9-15. doi:10.1016/S0378-8741(99)00136-1

[13] A. C. Reddy and B. R. Lokesh, "Studies on Spice Principles as Antioxidants in the Inhibition of Lipid Peroxidation of Rat Liver Microsomes," Molecular and Cellular Biochemistry, Vol. 111, No. 1-2, 1992, pp.117-124.

[14] PS. Babu and K. Srinivasan, "Hypolipidemic Action of Curcumin, the Active Principle of Turmeric (Curcuma Longa) in STZ Induced Diabetic Rats," Molecular and Cellular Biochemistry, Vol. 166, No. 1-2, 1997, pp. 169175. doi:10.1023/A:1006819605211

[15] S. Tripathi, R. Nagarathna, H. R. Nagendra, "Validation of an Integrated Ayurveda-Yoga Module for Residential Treatment of Patients with Type 2 Diabetes Mellitus-A Compilation from Traditional Literature,” International Journal of Applied Mechanics, Vol. 2, No. 5, 2012, pp. 921-934.

[16] G. K. Garde, “Sartha Vaghbhata,” In: Sutrasthana, Raghuvamshi Publishers, Pune, 1996, p. 8.

[17] R. Monro, J. Powar, R. Nagarathna and P. Dandona, "Yoga Therapy for NIDDM-A Control Trial," Journal of Complementary Medicine Research, Vol. 6, No. 2, 1992, pp. 66-68.

[18] S. V. Hegde, P. Adhikari, S. Kotian, V. J. Pinto, S. D' Souza and V. D'Souza, "Effect of 3-Month Yoga on Oxidative Stress in Type 2 Diabetes with or without Complications: A Controlled Clinical Trial," Diabetes Care, Vol. 34, No. 10, 2011, pp. 2208-2010.

[19] R. K. Yadav, R. B. Ray, R. Vempati and R. L. Bijlani, "Effect of a Comprehensive Yoga-Based Lifestyle. Modification Program on Lipid Peroxidation,” Indian Journal of Physiology and Pharmacology, Vol. 49, No. 3, 2005, pp. 358-362.

[20] V. Malhotra, S. Singh, O. P. Tandon and S. B. Sharma, "The Beneficial Effect of Yoga in Diabetes," Nepal Medical College, Vol. 7, No. 2, 2005, pp. 145-147.

[21] S. Singh, V. Malhotra, K. P. Singh, S. V. Madhu and O. P. Tandon, "Role of Yoga in Modifying Certain Cardiovascular Functions in Type 2 Diabetic Patients,” Journal of the Association of Physicians of India, Vol. 52, 2004, pp. 203-206.

[22] V. Malhotra, S. Singh, O. P. Tandon, S. V. Madhu, A. Prasad and S. B. Sharma, "Effect of Yogasanas on Nerve Conduction in Type 2 Diabetes," Indian Journal of Physiology and Pharmacology, Vol. 46, No. 3, 2002, pp. 298-306.

[23] S. C. Jain, A. Uppal, S. O. Bhatnagar and B. Talukdar, “A Study of Response Pattern of Noninsulin Dependent Diabetics to Yoga Therapy,” Diabetes Research and Clinical Practice, Vol. 19, No. 1, 1993, pp. 69-74. doi:10.1016/0168-8227(93)90146-V

[24] M. Kosuri and G. Sridhar, "Yoga Practice in Diabetes Improves Physical and Psychological Outcomes,” Meta- 
bolic Syndrome and Related Disorders, Vol. 7, No. 6, 2009, pp. 515-517. doi:10.1089/met.2009.0011

[25] A. K. Tiwari and J. M. Rao, "Diabetes Mellitus and Multiple Therapeutic Approaches of Phytochemicals: Present Status and Future Prospects,” Current Science, Vol. 83, No. 1, 2002, pp. 30-38.

[26] American Diabetes Association, "Standards of Medical Care in Diabetes-2011”, American Diabetes Association Diabetes Care, Vol. 34, No. 1, 2011, pp. S11-S61.

[27] G. K. Garde, “Sartha Vaghbhata,” In: Sutrasthana, Raghuvamshi Publishers, Pune, 1996, p. 35.

[28] K. N. Shastri and G. N. Chaturvedi, "Agnivesha's Charaka Samhita, Vidyotini Commentary,” In: Chikitsasthana, Chaukhamba Bharati Academy, Varanasi, 2004, p. 235.

[29] G. M. Shastri, “Bhavprakash,” In: Chikitsa Prakarana Verse 117-118, Sastu Sahitya Vardhaka Karyalaya, Ahmedabad, 1966, p. 1117.

[30] G. K. Garde, “Sartha Vaghbhata,” In: Sutrasthana, Raghuvamshi Publishers, Pune, 1996, p. 338.

[31] D. K. Nishteswar and R. Vidyanath, “Sahasrayogam,” In: Prameha Prakarana, Chawkhamba Samkrit Series Office, Varanasi, 2006, p. 30.

[32] D. K. Nishteswar and R. Vidyanath, “Sahasrayogam,” In: Prameha Prakarana, Chawkhamba Samkrit Series Office, Varanasi, 2006.

[33] S. Ambikadutta, "Bhaishajyaratnavali,” In: Pradararoga Chikitsa, Chowkhamba Samskrit Academy, Varanasi, 2008, p. 1035.

[34] B. K. Sahay, "Role of Yoga in Diabetes," Journal of the Association of Physicians of India, Vol. 55, 2007, pp. 121126.

[35] S. Despande, H. R. Nagendra and R. Nagarathna, "A Randomized Control Trial of the Effect of Yoga on Gunas (Personality) and Health in Healthy Volunteers,” International Journal of Yoga, Vol. 1, No. 1, 2008, pp. 210. doi:10.4103/0973-6131.36785

[36] P. Trinder, “Analysis of Glucose,” Ann Clin Biochem, Vol. 6, 1969, p. 24.

[37] D. M. Nathan, D. E. Singer, K. Hurxthal and J. D. Goodson, "The Clinical Information Value of the Glycosylated Hemoglobin Assay,” The New England Journal of Medicine, Vol. 310, No. 6, 1984, pp. 341-346. doi:10.1056/NEJM198402093100602

[38] J. D. Artiss and B. Zak, "Measurement of Cholesterol Concentration,” In: N. Rifai, G. R. Warnick and M. H. Dominiczak, Eds., Handbook of Lipoprotein Testing, AACC Press, Washington, 1997, pp. 99-114.

[39] W. T. Friedewald, R. I. Levy and D. S. Fredrickson, "Estimation of the Concentration of Low Density Lipoprotein Cholesterol in Plasma without the Use of Preparatory Centrifuge," Clinical Chemistry, Vol. 18, 1972, pp. 499503.

[40] A. Saxena and N. K. Vikram, "Role of Selected Indian Plants in Management of Type 2 Diabetes: A Review," Journal of Alternative and Complementary Medicine, Vol. 10, No. 2, 2004, pp. 369-378. doi:10.1089/107555304323062365
[41] S. Amita, S. Prabhakar, I. Manoj, S. Harminder and T. Pavan, "Effect of Yoga-Nidra on Blood Glucose Level in Diabetic Patients," Indian Journal of Physiology and Pharmacology, Vol. 53, No. 1, 2009, pp. 97-101.

[42] S. Singh, V. Malhotra, K. P. Singh, S. V. Madhu and O. P. Tandon, "Role of Yoga in Modifying Certain Cardiovascular Functions in Type 2 Diabetic Patients,” Journal of the Association of Physicians of India, Vol. 52, 2004, pp. 203-206.

[43] H. H. Mahapure, S. U. Shete and T. K. Bera, "Effect of Yogic Exercise on Super Oxide Dismutase Levels in Diabetics," International Journal of Yoga, Vol. 1, No. 1, 2008, pp. 21-26. doi:10.4103/0973-6131.36792

[44] W. F. Paul, M. Jose-Luis, H. H. Anne and J. W. Nicholas, "Gene-Lifestyle Interaction on Risk of Type 2 Diabetes," Nutrition, Metabolism and Cardiovascular Diseases, Vol. 17, No. 2, 2007, pp. 104-124. doi:10.1016/j.numecd.2006.04.001

[45] E. Y. Jung, S. K. Young, R. C. Mi and R. Choue, "Ratio of Fat to Energy Intake Independently Associated with the Duration of Diabetes and Total Cholesterol Levels in Type 2 Diabetes," Nutrition Research and Practice, Vol. 5, No. 2, 2011, pp. 157-162. doi:10.4162/nrp.2011.5.2.157

[46] A. Fauci, E. Braunwald, D. Kasper, S. Hauser, D. Longo, J. Jameson and J. Loscalzo, "Diabetes Mellitus. Harrisons' Principles of Internal Medicine,” McGraw-Hill, Boston, 2008.

[47] H. L. Fehm, W. Kern and A. Peters, "The Selfish Brain: Competition for Energy Resources," Progress in Brain Research, Vol. 153, 2006, pp. 129-140. doi:10.1016/S0079-6123(06)53007-9

[48] S. C. Woods, S. C. Benoit and D. J. Clegg, "The BrainGut-Islet Connection,” Diabetes, Vol. 55, Suppl. 2, 2006, pp. S114-S121. doi:10.2337/db06-S015

[49] J. S. Yudkin, “Adipose Tissue, Insulin Action and Vascular Disease: Inflammatory Signals,” International Journal of Obesity, Vol. 27, Suppl. 3, 2003, pp. S25-S28. doi:10.1038/sj.ijo.0802496

[50] S. Lokeswarananda, “Taittireya Upanishad,” The Ramakrishna Mission Institute of Culture, Kolkatta, 1996.

[51] S. A. Dutta, "Sushruta Samhita,” In: Nidanasthana, Chaukhamba Bharati Academy, Varanasi, 2007, pp. 251-252.

[52] K. N. Shastri and G. N. Chaturvedi, “Agnivesha’s Charaka Samhita,” In: Chikitsasthana, Chaukhamba Bharati Academy, Varanasi, 2004, pp. 228-229.

[53] K. N. Shastri and G. N. Chaturvedi, "Agnivesha's Charaka Samhita Vidyotini Commentary,” In: Chikitsasthana, Chaukhamba Bharati Academy, Varanasi, 2004, p. 243.

[54] K. N. Shastri and G. N. Chaturvedi, “Agnivesha’s Charaka Samhita,” In: Chikitsasthana, Chaukhamba Bharati Academy, Varanasi, 2004, pp. 234-235

[55] R. Nagarathna and H. R. Nagendra, "Integrated Approach of Yoga Therapy for Positive Health,” Swami Vivekananda Yoga Prakashana, Bangalore, 2008. 